\title{
DOI: 10.7596/taksad.v8i3.2222
}

Citation: Rastrygina, A., Koloskova, Z., \& Nazarenko, M. (2019). The Model of the Spirituality of Upbringing in the Dimension of Modern Paradigmatic Shifts. Journal of History Culture and Art Research, 8(3), 125-137. doi:http://dx.doi.org/10.7596/taksad.v8i3.2222

\section{The Model of the Spirituality of Upbringing in the Dimension of Modern Paradigmatic Shifts}

\section{Alla Rastrygina ${ }^{1}$, Zhanna Koloskova $^{2}$, Maryna Nazarenko ${ }^{3}$}

\begin{abstract}
The article presents the authors' position on the possibilities of using the concept of the spirituality of upbringing as a model that can become an effective basis in creating the latest paradigm of education. This makes it possible to solve the cultural-educational and socio-pedagogical problems that exist in modern higher education and are actualized in the era of globalization. It helps to return to higher education its status of the center of the forming of the spirituality of people on the principles of cultural-creative self-development and self-realization. The article also reveals conceptual foundations of the considered model, which are presented as vectors that stipulate the introduction of the phenomenon of the spirituality of upbringing into the educational practice of both, the higher education and education in general, by the subjects of the educational process. Particular attention is given on the outlining and substantiating of a fragment of the modern educational reality - the spirituality of upbringing as a phenomenon that is being transformed by the subjects of the upbringing process here and now, and reflects the becoming and maturity of each participant of this process and his role as a subject of the social environment. It determines and systematizes the development of the modern democratic culture of society. The introduction of the concept of spirituality of upbringing into the modern educational space as a model of the newest paradigm of education enables practical implementation of the phenomenon of the spirituality of upbringing - the inspiring of the environment, which is being transformed by the subjects.
\end{abstract}

Keywords: The newest paradigm of education, Modern educational models, Spiritual and creative development of personality, Spirituality of upbringing, Transformation of the environment.

\footnotetext{
${ }^{1}$ Doctor of Pedagogical Science, Full Professor, Head of the Department of vocal-choral disciplines and methods of musical education, Volodymyr Vynnychenko Central Ukrainian State Pedagogical University, Kropyvnytskyi, Ukraine. rastrygina.alla@gmail.com

2 Ph.D., Senior Lecturer at the Department of vocal-choral disciplines and methods of musical education, Volodymyr Vynnychenko Central Ukrainian State Pedagogical University, Kropyvnytskyi, Ukraine. zhabakva@ukr.net

${ }^{3}$ Ph.D., Senior Lecturer at the Department of vocal-choral disciplines and methods of musical education, Volodymyr Vynnychenko Central Ukrainian State Pedagogical University, Kropyvnytskyi, Ukraine. marunakondratyuk67@gmail.com
} 


\section{Introduction}

Transformations taking place in the living space of a modern person, - considering the postmodernist tendencies and globalization processes, aimed at creating a planetary information society, a unified economic system, and the universalization of culture, - require a moderate awareness of contradictions that arise today in this connection. The positive effects of globalization, which, thanks to economic and technological innovations in all spheres of life, the industrial revolution, and the establishment of market relations, have contributed to the progress of humanity. At the same time, according to Ukrainian and foreign scholars, these processes create the basis for further transformation in human consciousness, with far-reaching ambiguous consequences for each personality. It is difficult not to agree with scientists, who observe that because of globalization, technology, and sociotechnology more and more obviously become the regulator of social life instead of culture, people generally lose their central importance, turning into an object of manipulation, the "human capital".

The echo of these problems and contradictions also affects Ukraine, which actively seeks to join European priorities. Since the humanistic values of a democratic society, the fundamental principles of which are freedom and responsibility of a man for his personal choice, his aiming at success, and development of such socially significant personal qualities as independence, initiative, self-expression, and self-fulfillment in one's own life, have been chosen as the basis for the development of Ukraine, it is extremely important to keep to the mentioned principles on the way to self-realization. Therefore, there is an urgent need not only in comprehension of realities and possible consequences of globalization in the postmodern age but also in the elaboration of those perspective directions of development of modern society, which should be carried out in the name of preserving the identity of man as a personality. That is, the point is to develop such a culture of mankind, that the proclaimed many centuries ago by M. Krebs's slogan: "Homo non vis esse nisi homo" (Man does not want to be anything other than man) (Gorskyi, 2006) should remain its paradigmatic ground in new conditions.

The joining of Ukraine to European civilization is determined not only by the peculiarities caused by globalization. An essential role is played by the specificity of the current state of Ukrainian society as a socio-cultural integrity that performs the transformation and has to direct efforts to the developing of those types of cultural activities that lead to truly creative and critical intercultural communication. That, presently, is very important for the Ukrainian culture to attach to the globalized "We", preserving the sense of identity of our everyone's own "I", and especially of the "spiritual I" (Bekh, 2016). And this is necessary not only in order to avoid the threat of unification, but also for the development of each personality on the basis of the very humanistic values of a democratic society, the determining sign of which is the desire to comprehend the meaning of human existence, not only in its material, but also in spiritual manifestations.

Therefore, the development of a modern education paradigm that allows a subject of the educational environment to exercise his right to live, learn and work on the basis of democratic values 
is of paramount importance for education, since the world has always been, is and will be the product of the spirit and hands of a self-evolving personality.

\section{Formulation of the problem}

Higher education, as a derivative of culture, has been at all times remaining the source of cultural traditions and the center, where the people's spirituality develops. Therefore, the priority directions of reforming the national system of education in general and higher education in particular, the main substantive characteristics of which are fundamentalization, democratic principles, and humanistic orientation (Law of Ukraine, 2018) should, logically, be determined on the basis of the newest educational paradigm. In conditions of globalization the need for the newest educational paradigm is predetermined by basic aspects of education (biological, social, humanistic) (Podolskaia, 2010) and by the urgency of solving the existing globalization problems in order to redefine the cultural field of the nation and help the man in his self-development and spiritual ascent.

Numerous scientific researches, devoted to problems of modern higher education, raise questions related to realization of the tasks set before the higher school, concerning the basic scientific, general cultural, theoretical and practical training of specialists, which should determine the pace and level of scientific and technical, economic, social and cultural progress, and shape the nation's intellectual potential on the basis of humanization and democratization of education policy (Bilotserkivska, 2014). But at the same time, the new Law of Ukraine "On Higher Education" (2016), which regulates the work of universities, reads that its main purpose is to prepare competitive human capital for high-tech and innovative development of the country, to meet the needs of society, labor market and the state in qualified professionals.

Similar rhetoric regarding the "formation of a competitive, highly qualified specialist... who meets the needs of modern development of the national economy", we find almost in every study of domestic scholars, who address the problems of reforming modern higher education. Therefore, it is quite obvious that higher education now looks like a certain sector of the economy, and its basic categories such as science and culture are considered today exclusively in the system of commodity relations.

Therefore, there is a concern not only about the loss of identity of education as such, which has always been the source of cultural traditions and the center of formation of spirituality of the people, concern is caused by transformation of modern cultural space of higher education for the sake of commodification (Karpov, 2012). It is absolutely correct to say that introduction of "commodification" principles into the sphere of higher education in terms of providing educational services and their consuming, destroys profound meaning and sense in the developing spirituality of higher education, since the above criteria of evaluation are not able to capture the "quality" of the spiritual world, the authenticity of a personality's freedom, the individual trajectory of spiritual and creative growth of a personality. Thus, in our deep conviction, the awareness of the fact that modern education and upbringing in general, and higher education and upbringing in particular, need to 
function on the basis of just the humanistic values, should become the basis in building the newest educational paradigm of the 21 st century.

So, the need of introducing, within the frames of humanistic paradigm, such models of education that would really meet the requirements of the time and would be aimed at a personality and professional formation of a future specialist on the basis of spiritual and creative self-development and self-realization, becomes up-to-date. Such provisions gain their utmost specification within the concept of spirituality of upbringing, which, in our opinion, can become an effective basis in creating the newest paradigm of education (Rastrygina, 2018).

We believe that it is the model of spirituality of education that in the process of exploring the co-evolution of a personality and environment confirms the humanistic strategy of the newest educational paradigm of the 21st century, is capable of eliminating the problem of commodification, still existing in higher education (as well as in artistic education), and of returning to higher education its status of the center of formation of spirituality of the people based on cultural and creative selfdevelopment and self-realization of a personality

The purpose of the article is to substantiate the feasibility of introducing the model of spirituality of upbringing into the newest paradigm of education.

The achievement of this goal becomes possible due to the solving of the following tasks:

- To outline the cultural, educational and socio-pedagogical problems of education and upbringing in general and the higher ones in particular, which in the age of globalization become up-to-date;

- To substantiate the feasibility of updating the model of spirituality of upbringing in the modern educational space;

- To reveal the key categories of the model of spirituality of upbringing as the basis for the introduction of the latest educational paradigm into the artistic-educational space of the university;

- To outline the conditions of the effective functioning of the artistic educational space of the university on the basis of the model of spirituality of upbringing.

\section{Background}

Exploring the transnational processes caused by globalization, the French scientists (Martin, 2005) emphasize that the transfer of the cultural sphere to market rails is a direct threat to dignity of an individual person, who in no circumstances can be considered as a "receiver" of the streams of cultural products he consumes. Moreover, focusing attention on the "Crisis of the Imagination of the Future" (Club of Rome), that is emerging in the context of the impending cultural unification, the scientists stand for the protection of cultural pluralism (and even for cultural uniqueness) as one of the last frontiers for the world that suffers from spiritual emptiness. 
Analyzing the existing in philosophy and the mostly used in education paradigms (traditionalist-conservative, technocratic, rationalistic, humanistic), which traditionally perform the function of "the system of coordinates" for the sake of comparing various pedagogical concepts, theories and approaches as to improving the system of education, in general, and of higher education, in particular, domestic scholars Bekh (2016), Lysyi (2013), Oleksyuk (2015), Otych (2015), and Chumak (2017) more and more frequently emphasize the need to determine the basic foundations of the modern paradigm of the 21 st century.

For example, Chumak, characterizing the models presented by domestic scientists as innovations in the modern educational paradigm (education as the process of forming the scientific picture of the world; education as professionalization; education as the process of forming the culture of mental activity; education as preparation for life; the concept of continuous education), reveals their peculiarities and thoroughly analyzes the advantages of each of them from the standpoint of their belonging to the humanistic tradition (Chumak,2017).

At the same time, the scientist emphasizes the expediency of appealing to the models, that are offered by foreign scientists, and which are of particular importance for the Ukrainian education on the way to real, not just declared realization of the humanistic essence of the paradigm, where "... its main link is to be an individual. The maximum disclosure of his or her individual abilities, unique and unrepeatable peculiarities of the psyche and intelligence become the main objective of the whole educational process" (Chumak, 2017). The components of this global objective are: the creation of conditions for the development of subjectivity, creativity, personality functions of a growing-up individual, the support for self-discovery, self-determination, and self-realization.

Most modern foreign educational models of humanistic direction are founded on the strategy of constructivism, based on the ideas of D. Dewey, J. Piaget, H. Gardner, regarding the need to discover the individual capabilities of each person, to develop his or her ability to think constructively, to solve problems constructively, and to continuously improve themselves.

The large-scale "Follow Through" study conducted in the United States, where freedom of a personality has long been recognized as the highest value, has become a testament to the effectiveness of the use of educational models, stipulated by the system of values of the society and the government. The results of such a study, conducted under the auspices of the US Department of Education for more than thirty years in American educational practice through the introduction of school development programs (School Development, Success for All, etc.), confirmed their effectiveness and made it possible to implement these programs in the national educational standards of the country.

Noteworthy is a New Paradigm for Undergraduate Education, proposed by American researchers R.B. Barr and J. Tagg (2012), which is based on a radically new interpretation of the essence of the process of training of a high school graduate on the basis of the critical-creative model, which has become a serious impetus for the radical rethinking of objectives, tasks, and organization of the educational process in US universities and colleges. The authors of the model "From Teaching to 
Learning" emphasize the fact that major problems facing higher education today cannot be solved at the same level of thinking as in the days of A. Einstein when the student's learning predominantly was to listen to a 50-minute lecture and to get concomitant instructions.

The main message of the aforementioned educational model has become the idea of reconstruction of the existing approaches to the process of training of a modern grade specialist: to fulfill not just teaching on the principle of "teacher conveys knowledge to students", but to teach each student to learn by whatever means. That is, to instill in students a conscious and responsible attitude to learning through the creation of an active learning environment or an inquiry learning context and other appropriate conditions in which the atmosphere of personal creativity prevails, and there is a desire for self-realization and self-realization.

Against the background of the rise of the educational role of art at the beginning of the 21st century and the need to overcome the challenges, existing in professional art education, the attention of some domestic scientists is attracted by holistic scientific- artistic paradigm. By stressing on the ability of art to make the content of education axiological, to enhance its creative direction and individualize the process of teaching and upbringing, the holistic paradigm redirects it to the development of essential forces and creative potential of a personality, which does not only consume cultural and artistic values, but it multiplies them as well, culturally enriching and realizing itself in the process (Koloskova, 2015; Nazarenko, 2018; Otych, 2015).

There is no doubt that today, in conditions of globalization, the Ukrainian scientists and practicing pedagogues make a lot of effort to implement the basic principles of humanistic pedagogy in the educational space of higher education institutions. They introduce concepts and modern pedagogical technologies aimed at the developing of a young man's self-awareness, regarding the realities of the globalized world, the need for an optimal balance between the local and the global, the ability to be responsible for it, that is to be a citizen of the country and a citizen of the world.

Absolutely supporting the right to exist and to further scientific and practical research of modern models of leading domestic scientists, aimed at implementing changes and coordination and convergence of educational systems, taking into account national and European peculiarities, we believe that the latest paradigm of education of the 21st century, should really, and not declaratively, reproduce at the social and individual level the understanding of an individual as the highest value. In other words, the conceptual approaches to the content and objectives of both the general and higher education need to be redefined, in which the latter is to ensure not only the training of a competitive specialist in the labor market, but also give him the right to be free in his vital and professional development and to provide, within the educational space of a university, opportunities for the awakening and developing of his spiritual potential, his personal and social cultivation.

\section{Conceptual Framework}

In view of the above, it should be emphasized that in conditions of globalization, when innovative changes must be made first and foremost, in order to preserve the identity of an individual as a personality, the delineation of the context of modern education in the newest educational 
paradigm, which is aimed at world-view reorientation of a person in order to acquire stable ground for his or her spiritual and creative self-development and self-realization, for the organization of his or her life on the basis of the democratic values inherent in the spirit of times, the concept of spirituality of education acquires the status of one of the most needed models, and this opens new horizons for spiritual growth of a personality in educational and upbringing environment of a higher education establishment.

A new perspective on the problem of spirituality of education, presented in the author's concept of a Lithuanian Professor I. Kevishas at the beginning of this century, the discussion of which, for the first time in Ukraine, was held among scientists of the Art Faculty of Kirovograd State Pedagogic University in 2007, against the background of academic dogmas, still existing at that time in the postSoviet space, about "purposeful upbringing of spirituality through the formation of certain personality traits", aroused interest, at a minimum. Although the author of the idea, offered for the rethinking, who at that time, even among some scholars of his native country, had the reputation of sort of a "trickster", a destroyer of established traditions, the one who "tries to reduce to a single consistent whole all possible contradictions" (Rastrygina, 2019), his concept attracted by its novelty, gave rise to new thoughts and our own pedagogical reflection.

Therefore, despite the fact that the theoretical foundations and fundamental principles of the above concept had not quite coincided with the theoretical and methodological mainstream of the Ukrainian pedagogical science of that time, several domestic scientists (Oleksyuk, Rastrygina, Khairulina) became the first who joined further research on the problem of spirituality of education.

The basis for creating I. Kevishas' concept of spirituality of education was his doctoral research on the problem of self-expression of a personality as a factor of formation of the culture of an individual, which is unthinkable without the manifesting the inner world of a person, the disclosing and realizing the spiritual values embedded in the culture. This research passed a long-term experimental test, both, at secondary schools and universities of Lithuania. In the next stage of the study, the author has already linked directly to spiritualization of the environment created by man, involving Lithuanian and foreign scientists in scientific exploration.

Fruitful collaboration of scholars of ten European countries, including Ukraine, resulted in publication of four collective monographs on spirituality in the human world: Spirituality in the Human World (2009), Spirituality of education (2012), Context of Spirituality of Education (2014), and Development of Spirituality of Education (2016). Due to the efforts of philosophers, pedagogues, psychologists, representatives of the clergy in the mentioned collective researches, a peculiar fragment of reality - the spirituality of education (2009) as a component and the problem of education (2012), has been identified and substantiated. In the process of further researches, the context of its existence (2014) has been defined, as well as possibilities for its development in the modern educational reality (2016). Against the background of such searches, the concept of spirituality of education has been formulated, which presents the theoretical foundations for the reconstruction of the content of 
traditional education, the spreading of which in the domestic educational space is now attracting attention of an increasing number of leading Ukrainian scholars.

The aspects of the study on spirituality of the environment, outlined in the monographs, can be, on the whole, presented as conceptual foundations, helping a person to better realize spirituality of the reality that surrounds him. Accordingly, spirituality of educational environment - spirituality of education - is been realized as well. In this case, the basic foundations of the concept of spirituality of education can be considered as vectors of search for a model, which here and now is able to confirm the existence of the mentioned phenomenon and to ensure its introduction into the modern educational environment of institutions of secondary and higher education in the context of actualization of the problem of creation of the latest education paradigm. Thus, the vectors of manifestation of the inner world of a personality, separated at the theoretical level, facilitate the formation of integrity of the concept of spirituality of upbringing and open possibilities for its introduction into the system of modern higher education. At a practical level, they help to systematize educational tasks regarding the integrity of becoming a personality in the process of professional activities and life activities as a whole. Thus, the mentioned model of spirituality of upbringing is particular for its dynamism and needs a more detailed study in the context of how the subjects create their modern educational reality.

The actualization of the problem of introducing the model of spirituality of upbringing into the modern system of education, in general, and into professional art education, in particular, is consistent with our conceptual ideas, which have been considered in the framework of the aforementioned monographs and are aimed, above all, at examining the specifics of the artistic and educational environment of the university and its inherent spirituality; at presenting the context of the spirituality of upbringing as a component of the upbringing reality, which ensures professional and personal becoming of a future teacher-musician; at determining the conditions of manifestation of spirituality of a future specialist and the possibilities of its development in the artistic and educational space of the university.

\section{Methods}

Polyparadigmatic approach, which combines such basic approaches as systemic, synergetic, personality-oriented, cultural and axiological, has become the methodological basis for the study of the model of spirituality of upbringing as the ground for the effective functioning of the newest paradigm of education of the 21st century. The application of each of these approaches has made it possible to identify important conceptual positions for the solving of the indicated problem. In particular, the determining of invariant components of the explored humanistic models on the basis of a systematic approach; considering of the interconnection of individual spiritually-creative resource of a personality and the artistic educational environment and their mutual influence in the development of the spirituality of upbringing on the ground of a synergistic approach; the focusing on the individuality and self-worth of a personality as a subject of artistic and creative communication on the basis of a personality-oriented approach; the achieving of cultural correspondence of the spiritual 
and creative activity of future specialists on the basis of culture-logical approach, which makes it possible to analyze existing models and concepts in the context of development of professional art education and artistic culture in general; the accepting of humanistic values of a democratic society at the level of subjective-value thinking over spiritual and cultural self-development of a personality and creative self-expression and self-realization in future professional activity on the basis of an axiological approach.

The objectification of the methodological foundations and basic conceptual provisions of the model of spirituality of upbringing has made it possible to prove its relevance in the context of the introduction of the newest education paradigm, to reveal the key categories of the concept of spirituality of upbringing and to determine the conditions for its effective functioning in the artistic educational space of higher education institutions.

\section{Discussion}

The components of the key category of the concept of "spirituality of upbringing" are such basic notions as "spirituality" and "upbringing". As for the former, the spirituality, in a generalized form, is a phenomenon of preserving the continuity of generations, positive tendencies in human development; the way of existence of a person, which corresponds to inner aspiration towards higher values that attach to human life and the whole human culture a higher dimension, higher meaning of sense. In this connection, spirituality is meant as the sense for the subjects to transform the environment, as a representation of the inner world of man in the social environment. Considering the subjective-personal format of interpreting the essence of upbringing as a socio-pedagogical phenomenon, its modern meaning is defined by the humanistic paradigm and is connected with the self-worth of a personality and its development, in which the spiritual origin is dominant (Rastrygina, 2018b).

In our opinion, the spirituality of upbringing is the sense, which appears in result of creating and spiritualizing of the educational space by its subjects: the expression of unity of personal and social spirituality. Therefore, the spirituality of upbringing, by its semantic content, is a personality reflection on the culture of environment and, in this respect, is a component of modern education. In this case, both undergo transformation, space, been reshaped by the subjects (educational reality), and the subject itself, that performs transformation (personality of the learner) change.

The long-lasting scientific explorations conducted within the aforementioned monographs have just confirmed that upbringing should be regarded as a continuous reconstruction of the understanding and the practice of manifestation of a personality's spirituality, when the inner world of a person (a personality as a spiritual being) is brought into social environment and it spiritualizes the environment, and this subjective sense, granted to it by man, is entrenched in the culture and stands out as a fragment of reality - the spirituality of the social environment and the upbringing environment as well. It is just such phenomena that the concept of spirituality of upbringing as the basis of upbringing and the factor of a personality becoming in the system of modern education is founded on. 
The ambiguity of globalization influences on the modern man, which, on the one hand, certainly involve him in the best achievements of civilization, and on the other, in the pursuit of competitiveness in the labor market, push to the background the development of his spirituality, demand for real, not declarative changes in the attitude to a personality and require to look for the new models of organization of its life, including the professional one. It is clear that any environment exists in the unity of the material and the spiritual. Therefore, a personality must transform both these spheres in their integrity. This is how the spirituality of the environment (a fragment of reality) emerges as a phenomenon and as the purpose of spiritualizing this environment in the process of its continuous transformation. Thus, the attention of society and of higher education, in particular, should now be directed primarily to development of a personality and to providing it with the status of the subject of transforming activity in contemporary reality.

In practice, changes in the environment, being transformed by the subject (in our case, the educational environment) most often take place due to the maturity of a personality, who consciously transforms the environment. Therefore, the modern upbringing as an integral component of education should be based on the appropriating by those who study, the status of the subject of upbringing environment, which, in the process of becoming of personal maturity, transforms the modern educational reality.

Such changes occur as a result of the implementation of the subjects' reconstruction of the pedagogical process as a way of transforming the artistic educational space and the becoming of personal qualities of a student, his subjective characteristics and his spiritual and creative potential.

Considering the fundamental positions of the model under consideration, we understand that the development of the spiritual and creative potential of the students of art faculties is one of the leading tasks of the functioning of professional art education in the context of the latest educational paradigm. That is, the artistic and educational space of the university is just the spiritual and cultural environment, where a personality does not only recognizes the peculiarities of local, national, European and world cultures by means of various types of art but also begins to realize his own identity and opportunities for the development of personal spiritual and creative potential. (Rastrygina, 2018b).

Spiritually creative potential, as an integrated category, is immanently inherent in art education and combines professional activity with personality development, spirituality and active humanistic position of a specialist. It is also directed at the developing of a creatively active personality capable of transformative activity in the field of art pedagogy. Therefore, the introduction of the latest educational paradigm into the artistic educational space of the university just on the basis of using the model of spirituality of upbringing acquires the special meaning related to the inclusion of a personality into the value-semantic world of culture. Mastering such a world determines the latest vision of the sociocultural purpose of modern qualified specialists in the field of art, who must possess not only a complex of relevant professional competencies, but also, due to the establishment of their spiritual 
and creative potential, ensure the introduction of artistic values into wide environment of the studying youth and turn culture and art into a means of a personality forming.

The artistic and educational space of the university is multidimensional and dynamic. Besides it is a direct teaching process, it also includes the upbringing component. And it is the latter that determines the forms of communication between the students, values of culture and art, significant events and symbols that are fundamental in determining the "world of culture" of a personality: its meanings, values, norms, ideals, professional successfulness.

That is, the effectiveness of the spiritual and creative development of a future specialist depends, on the one hand, on the content and quality of the artistic educational space in which he is included objectively, on the other hand, on his "counter activity" (Gatalsky) - a conscious desire for spiritual self-improvement and creative self-expression in professional activities. Such symbiosis can be achieved by creating optimal organizational and pedagogical conditions in the art educational space of the university, ensuring the inclusion of a personality in various types of sociocultural and professional-practical activities.

One of such conditions is the interaction of the teacher and student on the basis of pedagogical co-action, the main sign of which is reliance on the identity of the latter, when the students' community is responsible for the creation and improvement of the artistic and educational space. Then this space becomes a space filled with both the spiritual needs of students and the need to solve professional problems and, along with teachers, be subjects of their development. Students perceive such a space as their own territory, for which they are responsible, and it can become a factor in the spiritual and creative self-development of a future specialist.

An equally important condition for the successful functioning of the university's artistic and educational space is its dynamism and openness both to the creative use of the possibilities and cultural achievements of various types of art, and to the creative expression of a student in the process of his professional development. In such a situation, a new context of this space appears, new connections arise between the subjects of the upbringing process, allowing the student to realize and comprehend his or her creative abilities and spiritual intentions. That is, when the university's artistic educational space is not exposed to standards set from outside, when there is no formal, narrowly professional attitude to the understanding of its upbringing potential from the teachers' side, the likelihood of truly effective spiritual and creative development of future specialists becomes a reality.

The dialogue mode and the presence of an atmosphere of mutual understanding between all subjects of the educational process become relevant in such a process. The teacher presents his own professional positions and students accept them; thinking over and accepting by students the values of artistic educational space and providing them with the opportunity to choose the individual trajectory of their own spiritual and creative ascent. That is, the creation of a certain concept of the student's spiritual and creative professional and personal development, which is acceptable to all subjects of the educational process, is another condition for the innovative context of the university's artistic educational space in the framework of the latest education paradigm. 
Thus, the introduction of the model of spirituality of education, aimed at a personality and professional growth of a future specialist on the basis of spiritual and creative self-development and self-realization, can really ensure the student's approval as a subject of upbringing reality for the sake of reconstruction of traditional pedagogical process in the institutions of higher education, in general, and of artistic higher education, in particular, on the basis of the latest education paradigm. In our opinion, this should be connected with the use of isolated organizational and pedagogical conditions, the development of a didactic system for the practical implementation of the development of spirituality of upbringing in the University educational space. We believe that just this kind of perspective of scientific explorations as to horizons of development of spirituality of upbringing becomes a valid basis for the application of the model of spirituality of upbringing in the newest paradigm of education.

\section{Conclusion}

In the process of highlighting the problems that are currently occurring in the system of national education, in general, and higher education, in particular, and analyzing the scientific works of the leading domestic and foreign scientists, in which the issues of its reconstruction on the basis of humanistic values are relevant, the defining feature of which is the desire to grasp the meaning of human existence not only in its material but also in spiritual manifestations, we have made an attempt to substantiate the expediency of applying the concept of spirituality of upbringing as a basis for building the newest paradigm of education.

To confirm the effectiveness of introducing the concept of spirituality of upbringing in the modern domestic educational space as the model that meets the requirements of the time, aimed at spiritual and creative self-development and self-realization of a personality and able to return to education the status of the center of formation of spirituality of the people, we have revealed a number of fundamentals of the mentioned concept.

Particular attention was focused on outlining and substantiating of a fragment of modern educational reality - the spirituality of upbringing as a phenomenon that is transformed by the subjects of the educational process here and now, reflects the becoming and maturity of each of the participants in this process and its role as a subject of social environment and systematizes the development of modern democratic culture of the society. The introduction of the concept of spirituality of upbringing into the modern educational space as a model of the newest paradigm of education makes it possible to apply the phenomenon of spirituality of upbringing in a practical way: to inspire the environment, transformed by the subjects.

Thus, the unprecedented nature of the presented model in the measurement of modern paradigmatic shifts, the humanistic essence of which can become the cultural nucleus and basis in solving the problems of modern domestic education at all its levels, with its values, traditions and opportunities for the development of spiritual and creative potential of a personality is a valid basis for the introduction of the concept of spirituality of upbringing as the model of modern educational paradigm in the 21st century. 


\section{References}

Barr R. B., \& Tagg J. (2012). From Teaching to Learning /A New Paradigm for Undergraduate Education. Retrieved from: https://www.tandfonline.com/doi/abs/10.1080/00091383.1995.10544672.

Bekh, I. (2016). Dukhovnist osobystosti u paradygmalnomu predstavlenni. Teoretyko-metodychni problemy vykhovannia ditey ta uchnivskoi molodi, Kyiv

Bilotserkivska, N. (2014). Reformuvannia vyshchoi osvity v Ukraini: pravovi aspekty. Forum prava, 4, 11-17.

Chumak, O. (2017). Paradygma osvity XXI stolittya: inovatsiyni aspekty. Retrieved from: http://virtkafedra.ucoz.ua/el_gurnal/pages/vyp7/konf1/Chumak.pdf

Gorskyi, V. (2006). Bilia dzherel. Narysy z istorii filosofskoi kultury Ukrainy, Kyiv, 243-249.

Karpov, A. (2012). Kommodifikatsia obrazovania. Pedagogika, 2, 43-51.

Koloskova, Zh. (2016). Zaprovalzhennya kulturnyh tradytsii Elisavertadschyny yak zasib modernizatsii suchasnoi system muzychnoi osvity. Naykovi zapysky. Kirovograd, 143, 112-116.

Law of Ukraine. (2018). Retrieved from: https://zakon.rada.gov.ua/laws.

Lysyi, I. (2004). Philosophcka i mystetska Kultura, Kyiv.

Martin, D. (2005). Metamorphozy svitu. Sotsiologiya globalizatsii. Kyiv.

Nazarenko, M. (2018). The Integration Approach to Formation of Readiness of Future PedagogueMusician to Instrumental and Performing Activities. European vector of contemporary psychology, pedagogy, and social sciences: the experience of Ukraine and the Republic of Poland, (Vol.3, pp.227246). Sandomierz:

Oleksyuk, O. (2015). Duhovnist osobystosti v sysytemi mystetskoi osvity, Kyiv.

Podolskaia, E. (2010). Tseli vysshego obrazovania: korrektirovka v otvet na vyzovy vremeni. Sotsialnogumanitarnye vektory pedagogiki vyschoi sholy. Kharkiv.

Rastrygina, A. (2018a). Innovative and creative potential of the artistic educational space as a basis for the implementation of the newest paradigm of education of the 21st century. Scientific Notes. Kropyvnytskyi, 170, 17-22.

Rastrygina, A. (2018b). Model dukhovnosti vospitaniya v obrazovatelnom paradigmalnom prostranstve globalizovannogo mira. Applied Research in Studies and Practice, 14, 80-87

Rastrygina, A. (2019). The concept of education spirituality as a model of the latest education paradigm. The Horizon of Spirituality of Education. Vilnius, 128-143 